\title{
VIRŠUTINIŲJŲ VOKŲ DERMATOCHALAZĖS BLEFAROPLASTIKOS REIKŠMĖ PACIENTU REGĖJIMO FUNKCIJAI IR GYVENIMO KOKYBEI: KLINIKINIS ATVEJIS
}

\author{
Ieva Kaukẻnaitė ${ }^{1}$, Justė Čemerkaitė ${ }^{1}$, Rasa Liutkevičienė ${ }^{2}$ \\ ${ }^{1}$ Lietuvos sveikatos mokslu universitetas, Medicinos akademija, \\ ${ }^{2}$ Lietuvos sveikatos mokslu universitetas, Akiu ligu klinika
}

Raktažodžiai: dermatochalazė, blefaroplastika, regèjimo funkcija, pacientų pasitenkinimas.

\begin{abstract}
Santrauka
Dermatochalazė yra vokų odos perteklius, susiformuojantis dèl odos išsitampymo, sumažejjus jos elastingumui. Pagrindinis akių vokų odos užkritimą sukeliantis veiksnys yra su amžiumi susijęs odos senėjimas, tačiau mokslinèje literatūroje išskiriami ir kiti rizikos veiksniai, tokie kaip vyriškoji lytis, šviesesnè odos spalva, didelis kūno masès indeksas (KMI) bei rūkymas. Blefaroplastikos metu pašalinamos perteklinès vokų odos raukšlès, riebalai ir, jei reikia, gilesni audiniai. Viršutiniujų vokų blefaroplastika yra viena iš dažniausių veido plastinių operacijų, kuri gali būti atliekama dèl funkcinių ar estetinių indikacijų. Komplikacijos po šios chirurginès procedūros stebimos retai, daugumos jų išvengti padeda kruopštus operacijos planavimas bei tiksli metodika. Tyrimo tikslas - pristatyti klinikini atvejį ir, remiantis naujausiais mokslinès literatūros šaltiniais, apžvelgti viršutiniųjų vokų dermatochalazès blefaroplastikos reikšmę objektyviems ir subjektyviems regèjimo funkcijų pokyčiams, gyvenimo kokybei ir bendrą pacientų pasitenkinimą šios operacijos rezultatais. Pristatomas klinikinis atvejis, kuriame 57 metu moteriai buvo atlikta blefaroplastika dèl abiejų viršutiniųjų vokų odos, dengiančios išorinius vokų plyšio kraštus bei krentančios ant blakstienų, pertekliaus. Paciente skundèsi akipločio susiaurèjimu, viršutiniujų vokų sunkumo jausmu, odos dirginimu bei pasunkẻjusia žiūrèjimo pozicija. Viršutiniujjų vokų plastikos metu pašalinus odos perteklių, pagerèja pacientų regèjimo funkcija dèl viršutinès akipločio dalies defekto sumažèjimo, kontrastinio jautrumo padidèjimo, astigmatizmo ir aukštesnio lygio aberacijų sumažejimo. Subjektyvūs pacientų išsakomi simptomai, tokie kaip akipločio sumažèjimas,
\end{abstract}

galvos atlošimas siekiant geriau matyti, viršutiniujuc vokų sunkumo jausmas, galvos skausmai, viršutiniujų vokų odos dirginimas po jų plastikos pasireiškia rečiau, nei prieš operaciją. Po viršutiniujų voku plastikos pagerèja pacientų gyvenimo kokybè. Bendrasis pacientų pasitenkinimas operacijos rezultatais yra labai didelis.

\section{Ivadas}

Dermatochalazė yra vokų odos perteklius, susiformuojantis dèl odos išsitampymo, sumažejus jos elastingumui [1]. Tai su amžiumi susijusi būklè, kurios pasireiškimo dažnis tarp vyresnių nei 45 metų žmonių siekia 16 procentų [2]. Remiantis histopatologinio dermatochalazès tyrimo rezultatais, pirmasis patofiziologinis pokytis, formuojantis dermatochalazę, yra limfostazè. Padidèjęs makrofagų kiekis lemia elastinių skaidulų skilimą, kuris pasireiškia sumažèjusiu šių skaidulų pluošto tankiu. Elastinių skaidulų tinklo, atliekančio limfagysles palaikančios stuktūros funkciją, suardymas silpnina limfos drenažą ir sukelia limfedemą [1]. Pagrindinis akių vokų užkritimą sukeliantis veiksnys yra odos senëjimas, tačiau mokslinejje literatūroje išskiriami ir kiti negenetiniai rizikos veiksniai, tokie kaip vyriškoji lytis, šviesesnè odos spalva, aukštas kūno masès indeksas bei rūkymas. Skirtumas tarp vyrų ir moterų galimas dẻl lyčiai būdingų hormoninių bei veido formos skirtumų. Padidèjęs KMI susijęs su odos nusvirimu žemyn ir sumažejusiu odos elastingumu. Šviesi oda ir rūkymas galimai turi ịtakos dermatochalazès susiformavimui dèl padidejjusios elastozès. Itakos gali turèti ir genetinis polinkis [3]. Viršutiniųų vokų blefaroplastika yra viena iš dažniausių veido plastinių operacijų, kuri gali būti atliekama dèl funkcinių ar estetinių indikacijų. Šios chirurginès procedūros metu pašalinamos perteklinès vokų odos raukšlès, riebalai ir, jei reikia, gilesni audiniai [2].

Tyrimo tikslas - pristatyti klinikinị atveji ir, remiantis naujausiais mokslinès literatūros šaltiniais, apžvelgti viršutiniųjų vokų blefaroplastikos reikšmę objektyviems ir subjek- 
tyviems regėjimo funkcijų pokyčiams, gyvenimo kokybei ir bendrą pacientų pasitenkinimą operacijos rezultatais.

\section{Klinikinis atvejis}

57 metų moteris $2021 \mathrm{~m}$. kovo mèn. atvyko į Lietuvos sveikatos mokslų universiteto ligoninès Kauno klinikų (LSMUL KK) akių ligų klinikos dienos chirurgijos skyrių operaciniam gydymui - viršutiniųų vokų blefaroplastikai. Pacientė skundėsi viršutiniųjų vokų odos pertekliumi, varginančiu pastaruosius 5 metus, blakstienų dengimu oda, verčiančia blakstienas į vidų bei akipločio susiaurèjimu. Objektyvaus ištyrimo metu patvirtintas abiejų viršutiniųu vokų odos perteklius, dengiantis išorinius vokų plyšio kraštus bei krentantis ant blakstienų. Biomikroskopijos metu stebètos skaidrios ragenos, vidutinio gylio priekinès kameros, ramios rainelès, kiek paryškintos lęšiukų struktūros. Abiejų akių regos nervų diskai buvo gelsvai rausvi, riboti, su miopiniais konusais, geltonosios dèmès srityje pakitimu nebuvo, tinklainès prigludusios. Pacientei nustatytos gretutinès ligos - prasidedanti abiejų akių senatvinè katarakta ir trumparegystè. Abiejų akių regèjimo aštrumas buvo 0,1 , koreguotas iki 1,0 pritaikius $-4,0$ D korekciją. Dešiniosios akies akispūdis, išmatuotas automatiniu tonometru, buvo 16,3 mmHg, o kairiosios - 15,7 mmHg. Remiantis medicininèmis indikacijoms, atsižvelgiant ị pacientès išsakytus viršutiniųjų vokų odos pertekliaus sukeliamus regejjimo funkcijos sutrikimus, nuspręsta atlikti planinę viršutiniųų vokų blefaroplastikos operaciją.

Operacinis laukas buvo paruoštas ịprastiniu būdu, žymekliu pažymètos pjūvių vietos (kiek reikia pašalinti perteklinès odos), atliktas nuskausminimas lidokaino $2 \%$ $2,0 \mathrm{ml}$ ir adrenalino $0,1 \% 0,1 \mathrm{ml}$ tirpalu. Operacijos metu per viršutinio voko odos klostę padarytas lygiagretus voko briaunai pjūvis ir žirklutemis pašalintas perteklinis odos lopelis. Pašalintos riebalinès išvaržos iš medialinių kampų. Kraujavimas sustabdytas diatermokoaguliatoriumi. Žaizdos kraštai atpalaiduoti tiek, kad nebūtų odos tempimo, susiūti ištisine intrakutanine siūle. Uždètas sterilus tvarstis. Pacientę išleižiant ị namus, rekomenduota lašinti ciprofloksacino $0,3 \%$ akių lašus ị abi akis $3 \mathrm{k}$./d. ir pooperacines žaizdeles tepti deksametazono (chloramfenikolio) $1 \mathrm{mg} / 2$ $\mathrm{mg} / \mathrm{g}$ tepalu $2 \mathrm{k}$./d. Praejus 14 dienų po operacijos, pacientė atvyko šalinti siūlų ir teigè, jog prieš operaciją varginusių simptomų, tokių kaip akipločio sumažèjimas, viršutiniųų vokų sunkumo jausmas, odos dirginimas nebejaučia, jai nereikia atlošti galvos atgal, siekiant geriau matyti. Pacientė išsakè pasitenkinimą esamu akių vokų estetiniu vaizdu. Operacija atlikta sėkmingai, komplikacijų nepasireišké, iki operacijos varginę simptomai išnyko, pacientė viršutiniųjų vokų blefaroplastikos rezultatą įvertino puikiai. Nuotraukos prieš ir po operacijos pateikiamos 1 paveiksle.

\section{Diskusija}

Viršutiniujų vokų blefaroplastika gali būti atliekama siekiant pagerinti regejjimo funkciją arba dèl estetinių priežasčių. Nustatyti objektyvius kriterijus, kuriais remiantis būtų galima atskirti, kuriems pacientams ši operacija reikalinga dèl medicininių indikacijų, yra sudètinga. $2011 \mathrm{~m}$. Amerikos oftalmologų akademija (AOA) po atliktos mokslinès literatūros analizès pateikè kriterijus, kuriais remiantis po viršutiniujų vokų plastikos regèjimo funkcija reikšmingai pagerẻja [4]. Buvo išskirti šie kiekybiniai požymiai: atstumas nuo viršutinio voko krašto iki centrinio ragenos šviesos reflekso (apytiksliai atitinkančio vyzdžio centrą ir regos aši) (angl. margin reflex distance, MRD) $\leq 2 \mathrm{~mm}$ matuojant žiūrèjimo tiesiai metu; viršutinès akipločio dalies defektas 12 laipsnių arba 24 proc.; MRD $\leq 2 \mathrm{~mm}$ matuojant žiūrèjimo žemyn metu, kartu esant skaitymo sutrikimui dèl viršutiniųjų vokų nusileidimo žiūrint žemyn. M. Fuller su bendraautoriais nustatė, kad po viršutiniujų vokų plastikos MRD padidejjo vidutiniškai $0,8 \mathrm{~mm}$ ir šis skirtumas buvo statistiškai reikšmingas [5]. Mokslinejje literatūroje aprašomas ir atstumo tarp perteklinès viršutinio voko odos krašto ir vyzdžio centro vidutinis padidejjimas $1,59 \mathrm{~mm}$ [6], vertikalaus vokų plyšio matmens padidejimas 7,63 mm [7] po blefaroplastikos. Viršutinès akipločio dalies dydis ịprastai yra apie 50 laipsnių, akipločio defektas gali atsirasti, kai MRD mažesnis nei 4 $\mathrm{mm}$, o kai MRD yra $2 \mathrm{~mm}$, viršutinès akipločio dalies dydis sumažèja apie 24-30 procentų [4]. Sisteminèje viršutiniųjų vokų blefaroplastikos rezultatų apžvalgoje nustatyta, kad po šios operacijos stebimas arba statistiškai reikšmingas viršutinės akipločio dalies defekto sumažèjimas, arba akipločio
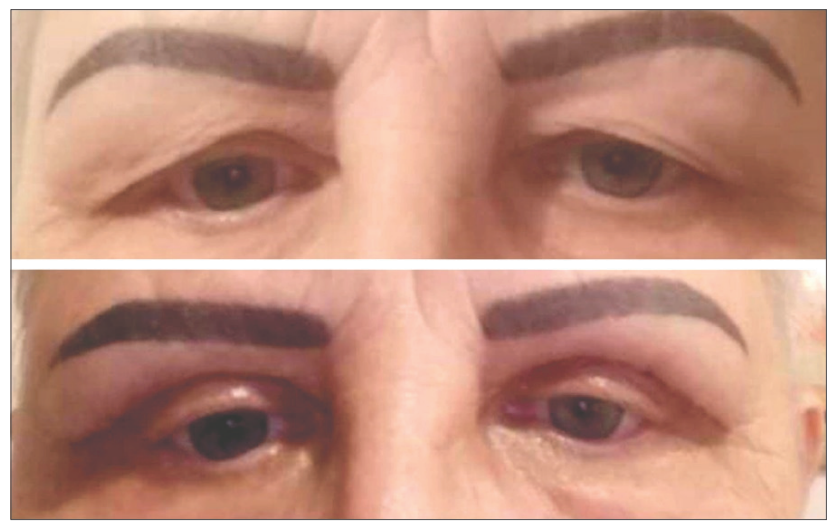

1 pav. Viršutiniųjų vokų būklè iki blefaroplastikos ir praejjus savaitei po operacijos 
defekto sumažèjimo tendencija [8]. Prognozuoti akipločio padidejjimą po operacijos gali būti sudètinga. J. Pemberton su bendraautoriais atliktoje studijoje tiriamujų, atvykusių viršutiniujų vokų plastikai, viršutinis akiplotis Goldmano perimetru buvo tiriamas prieš operaciją (vokui esant natūralioje pozicijoje ir pakèlus bei priklijavus viršutiniuju vokų odos perteklių) ir po operacijos [9]. Nustatyta, kad po operacijos akiplotis padideja labiau, nei tiriant prieš operaciją pakeltais ir priklijuotais vokais. Manoma, kad tokie rezultatai galèjo būti gauti dèl voko pakèlimo metu iškreipiamos voko pozicijos ir sutrikdomo regejimo. Nors ir priklijuotas, odos perteklius dèl mechaninio spaudimo gali sukelti viršutinès akipločio dalies defektus, todèl po operacijos galima tikètis geresnių rezultatų, nei tiriant prieš operaciją pakeltais vokais.

Po viršutiniujų vokų blefaroplastikos regejjimo funkcija pagerèja ne tik dèl akipločio defektų sumažèjimo. Prospektyviniame tyrime, kuriame dalyvavo 103 tiriamieji, nustatyta, kad po viršutiniujų vokų odos pertekliaus pašalinimo statistiškai reikšmingai padideja kontrastinis jautrumas, o dèl šios priežasties regimasis vaizdas tampa aiškesnis [10]. Kontrastinio jautrumo pokytis po operacijos buvo susijęs su MRD - kontrastinio jautrumo pagerejjimas buvo didesnis tiriamujų, kurių mažesnis MRD. Kontrastinio jautrumo pagerejjimą 3 mèn. po blefaroplastikos nustate ir S. An su bendraautoriais [7]. Jų atliktame tyrime kontrastinis jautrumas padidèjo visuose erdviniuose dažniuose, vertinant tiek fotopinemis, tiek skotopinèmis sąlygomis. Yra kelios hipotezès, aiškinančios šių operacijų įtaką kontrastiniam jautrumui. Pirma, manoma, kad voko priekinèje dalyje susiformavusios odos raukšlès sukelia akipločio defektus ir trukdo šviesos spinduliams pasiekti akies struktūras. Perteklinès viršutiniujų vokų odos raukšlès žemyn nukreipia blakstienas ir gali sukelti šviesos difrakciją. Sumažejja šviesos, pasiekiančios tinklainę, intensyvumas. Minètame S. An ir kitų tyrime buvo vertintas viršutiniujjų vokų blakstienų ptozès laipsnis nuo 0 iki 3, kai 0 balų reiške natūralią blakstienų poziciją, vertinant pagal voko kraštą (nesant blakstienų ptozès), o 3 balai reiškẻ sunkią blakstienų ptozę (blakstienos nukreiptos žemyn didesniu nei $45^{\circ} \mathrm{kampu}$, vertinant pagal horizontalų meridianą, išvestą pagal viršutiniojo voko kraštą) [7]. Prieš operaciją vidutinis blakstienų ptozès laipsnis buvo 2,6, o praejjus 3 mèn. po operacijos - 0,49 ir šis pokytis buvo statistiškai reikšmingas. Manoma, kad dèl blakstienų ptozès sukeltos šviesos difrakcijos korekcijos po blefaroplastikos pagerejja ne tik kontrastinis jautrumas, bet nustatomas ir aukštesnio lygio aberacijų sumažejjimas [10], dèl kurio matomas vaizdas yra aiškesnis. Viršutiniujų vokų odos pertekliaus ir riebalinių išvaržų sukeliamas mechaninis ragenos spaudimas gali sukelti jos išsigaubimo pokyčius ir astigmatizmą. Po blefaroplasti- kos stebimas statistiškai reikšmingas astigmatizmo dydžio sumažejjimas [10]. Nustatyta neigiama koreliacija tarp MRD ir astigmatizmo sumažèjimo (astigmatizmo dydis labiausiai sumažejo mažo MRD tiriamiesiems).

Remiantis vien objektyviais kiekybiniais parametrais, sudètinga įvertinti viršutiniųų vokų plastikos reikšmę pacientų regèjimo kokybei, regejjimo funcijų pokyčiams ir gyvenimo kokybei. Dėl šios priežasties AOA pateikia ir kokybinius kriterijus, kuriais remiantis po viršutiniujų vokų plastikos stebimas regejjimo funkcijos pagerejjimas [4]. Išsikiriami šie kriterijai: paciento išsakomas regèjimo sutrikimas, galvos atlošimas siekiant geriau matyti, regejjimo sutrikimas, sukeliantis sunkumų darbineje veikloje ir trukdantis saugumo užtikrinimui, diskomforto, akių nuovargio simptomai, atsirandantys dèl viršutiniujų vokų odos pertekliaus. Mūsų aprašomu klinikiniu atveju operacija buvo atlikta remiantis medicininemis indikacijomis pagal pacientès išsakomus subjektyvius simptomus. A. Jacobsen su bendraautoriais atliktame tyrime buvo vertinta, kaip dažnai pacientams su viršutiniųų vokų odos pertekliumi pasireikšdavo tokie simptomai, kaip akipločio sumažejjimas, galvos atlošimas atgal siekiant geriau matyti, vokų sunkumo jausmas, galvos skausmas, viršutiniujų vokų odos dirginimas, balais nuo 1 iki 5 (1 - niekada, 2 - retai, 3 - kartais, 4 - dažnai, 5 - visada) [6]. Visi pacientai nurodè visų minètų simptomų sumažèjimą po operacijos, o labiausiai sumažèjo vokų sunkumo jausmas (nuo 4 iki 1 balo). Remdamiesi šio tyrimo metodika, mes paprašème mūsų aprašomos pacientès ịvertinti tų pačių simptomų pasireiškimo dažnị iki blefaroplastikos ir 2 mèn. po jos. Pacienté nurodè, kad prieš operaciją tokius simptomus kaip galvos atlošimą siekiant geriau matyti ir viršutiniųjų vokų odos dirginimą ji jautè visada (5 balai), o akipločio sumažejimą ir viršutiniųjų vokų sunkumą jausdavo dažnai (4 balai). Po operacijos visi minèti simptomai išnyko - pacientė nurodè, kad jų nebejaučia niekada (1 balas). Toks simptomų sumažejjimas atitinka rezultatus, aprašomus mokslinėje literatūroje [6]. Moksliniame tyrime tiriamiesiems, kuriems viršutiniujų voku plastika buvo atliekama dèl akipločio viršutinès dalies defektų, besiskundžiantiems ilgiau nei 1 metus trunkančiais galvos skausmais, buvo pildomas galvos skausmo įtakos testas (angl. Headache Impact Test-6) prieš ir po operacijos, o atsakymų rezultatai palyginti su kontroline grupe [11]. Nustatyta, kad po viršutiniujų vokų plastikos galvos skausmai statistiškai reikšmingai susilpnejja. Manoma, kad vienas iš veiksnių, prisidedančių prie galvos skausmų pasireiškimo, gali būti kompensacinis lètinis kaktinio raumens susitraukimas, nustatomas esant ženkliam viršutiniujų vokų nusileidimui. Mūsų aprašomai pacientei prieš operaciją galvos skausmai buvo nebūdingi (šio simptomo pasireiškimo dažnumą ịvertino 1 balu). Pirminių galvos skausmų pasireiš- 
kimą gali sukelti ịvairūs veiksniai, iš kurių vienas galimai yra viršutiniujų vokų odos perteklius.

Po viršutiniujų vokų plastikos stebimas ne tik objektyvus ir subjektyvus regos funkcijų pagerẻjimas, tačiau ir teigiama itaka pacientų gyvenimo kokybei [12]. Po blefaroplastikos pacientai jaučiasi labiau patenkinti savo išvaizda, labiau pasitikintys savimi ir patrauklesni. Vertinant gyvenimo kokybès pokyčius nustatyta, kad po operacijos pacientai statistiškai reikšmingai geriau jautèsi darbinejje aplinkoje, nustatyta statistiškai reikšminga teigiama ịtaka tiriamujų gebẻjimui judèti, mažesnis kitų žmonių pagalbos poreikis bei didesnis emocinis stabilumas [12]. Tyrime, kuriame nepriklausomi stebetojai vertino tiriamujų moterų nuotraukas prieš ir po blefaroplastikos, nustatyta, kad po blefaroplastikos pacientès atrodè jaunesnès, patrauklesnès ir sveikesnès [13]. Ir tiriamosios, ir stebètojai pastebejo, kad po operacijos veide mažesni nuovargio požymiai. Tiriamiesiems ịvertinus savo patrauklumą prieš ir po 4 estetinių procedūrų (botokso injekcijų, veido pakèlimo procedūrų, lūpų putlinimo ir blefaroplastikos) nustatyta, kad po blefaroplastikos subjektyvus savo patrauklumo vertinimas padideja labiausiai, lyginant su kitomis minètomis estetinėmis procedūromis [14].

Komplikacijos po viršutiniujų vokų blefaroplastikos stebimos retai, mūsų aprašomu atveju jos taip pat nepasireiškè. Išvengti komplikacijų padeda kruopštus operacijos planavimas bei tiksli metodika. Pasireiškus nepageidaujamoms reakcijoms, svarbu anksti jas atpažinti ir pradèti tinkamai gydyti, siekiant išvengti nepalankios baigties [2]. Pati sunkiausia galima komplikacija yra aklumas, tačiau šios būklès pasireiškimo dažnis yra tik 0,0045 procento. Pati dažniausia komplikacija, kurios pasireiškimo dažnis siekia 0,05 proc., yra retrobulbarinè kraujosruva, ịprastai išryškèjanti 2-3 valandą po operacijos [15]. Kitos galimos komplikacijos yra vokų asimetrija, lagoftalmas ir ptozé, akių sausumas dèl suretėjusio mirksejjimo, chemozè, akių judrumo sumažèjimas dèl išorinių akies raumenų pažeidimo [16]. Nors ịprastai incizijos žaizda gyja labai gerai, galimas jos atsiverimas, hipertrofiniai randai, pigmentiniai pokyčiai [15]. Sèkmingas pooperacinis laikotarpis priklauso ir nuo paciento. Rekomenduojama pirmas 2 paras po operacijos $3-4$ kartus per dieną naudoti 10 minučiu šalčio aplikacijas, o po 3 parų galima rinktis šiltus kompresus, tokiu būdu švelniai nuplaunant vokų paviršių ir suminkštinant šašus, susidariusius chirurginès žaizdos vietose. Pacientams patariama miegoti ant nugaros, pasidejjus keletą pagalvių, kad galva būtų aukštesnèje padètyje. Dvi savaites po operacijos reikètų nenaudoti kontaktinių lęšių, kosmetikos priemonių, vengti saulès, fizinès veiklos, o 3-4 savaites nekelti sunkių daiktų, vengti kito intensyvaus fizinio krūvio. Kontrolininai apsilankymai skiriami po 3, 6 ir 12 mènesių [17]. Sąlyginè- mis kontraindikacijomis laikoma nekoreguota hipertenzija, koagulopatija ar kraujavimo sutrikimas, antiagregantu ir antikoaguliantų vartojimas, autoimuninès ligos [15].

Vertinant bendrą pacientų pasitenkinimą viršutiniųu voku plastikos rezultatais, nustatyta, kad didžioji dalis pacientų po šios operacijos būna labai patenkinti $[6,12]$. Šiuos rezultatus patvirtina ir mūsų aprašytas klinikinis atvejis, kuriame paciente, paprašyta operacijos rezultatus įvertinti balais nuo 1 iki 5, ivvertino juos aukščiausiu balu (5) - „puikiai“. Viršutiniujų vokų plastika yra gerai toleruojama operacija, turinti žemą komplikacijų pasireiškimo dažni [12], po kurios stebimi teigiami pacientų regos funkcijų, estetinio vaizdo, gyvenimo kokybės pokyčiai ir didelis pasitenkinimas operacijos rezultatais.

\section{Išvados}

1. Viršutiniujų vokų plastikos metu pašalinus odos perteklių, pagerèja pacientų regèjimo funkcija dèl viršutinès akipločio dalies defekto sumažèjimo, kontrastinio jautrumo padidejimo, astigmatizmo ir aukštesnio lygio aberacijų sumažèjimo.

2. Subjektyvūs pacientų išsakomi simptomai, tokie kaip akipločio sumažejjimas, galvos atlošimas siekiant geriau matyti, viršutiniujų vokų sunkumo jausmas, galvos skausmai, viršutiniųjų vokų odos dirginimas po jų plastikos pasireiškia rečiau, nei prieš operaciją.

3. Po viršutiniųų vokų plastikos pagerejja pacientų gyvenimo kokybė. Bendras pacientų pasitenkinimas operacijos rezultatais yra labai didelis.

\section{Literatūra}

1. Karnaz A, Katircioglu YA, Ozdemir ES, Celebli P, Hucumenoglu S, Ornek F. The histopathological findings of patients who underwent blepharoplasty due to dermatochalasis. Semin Ophthalmol 2018;33(3):407-11.

https://doi.org/10.1080/08820538.2017.1282970

2. Bhattacharjee K, Misra D, Deori N. Updates on upper eyelid blepharoplasty. Indian J Ophthalmol 2017;65(7):551-8.

https://doi.org/10.4103/ijo.IJO_540_17

3. Jacobs LC, Liu F, Bleyen I, Gunn DA, Hofman A, Klaver CCW, et al. Intrinsic and extrinsic risk factors for sagging eyelids. JAMA Dermatol 2014;150(8):836-43.

https://doi.org/10.1001/jamadermatol.2014.27

4. Cahill KV, Bradley EA, Meyer DR, Custer PL, Holck DE, Marcet $\mathrm{MM}$, et al. Functional indications for upper eyelid ptosis and blepharoplasty surgery: a report by the American academy of ophthalmology. Ophthalmology 2011;118(12):2510-7.

https://doi.org/10.1016/j.ophtha.2011.09.029

5. Fuller ML, Briceno CA, Nelson CC, Bradley EA. Tangent screen perimetry in the evaluation of visual field defects associated 
with ptosis and dermatochalasis. PLoS One 2017;12(3).

https://doi.org/10.1371/journal.pone.0174607

6. Jacobsen AG, Brost B, Vorum H, Hargitai J. Functional benefits and patient satisfaction with upper blepharoplasty - evaluated by objective and subjective outcome measures. Acta Ophthalmol 2017;95(8):820-5.

https://doi.org/10.1111/aos.13385

7. An SH, Jin SW, Kwon YH, Ryu WY, Jeong WJ, Ahn HB. Effects of upper lid blepharoplasty on visual quality in patients with lash ptosis and dermatochalasis. Int J Ophthalmol 2016;9(9):1320-4.

8. Hollander MHJ, Contini M, Pott JW, Vissink A, Schepers RH, Jansma J. Functional outcomes of upper eyelid blepharoplasty: a systematic review. J Plast Reconstr Aesthet Surg 2019;72(2):294-309.

https://doi.org/10.1016/j.bjps.2018.11.010

9. Pemberton JD, Salter M, Fay A, Thuro B, Spencer H, Dajani O. Investigation of goldmann perimetry in evaluation of patients for upper eyelid blepharoplasty. Orbit 2018;37(1):48-52. https://doi.org/10.1080/01676830.2017.1353115

10. Ekin MA, Ugurlu SK. Prospective analysis of visual function changes in patients with dermatochalasis after upper eyelid blepharoplasty. Eur J Ophthalmol 2020;30(5):978-84. https://doi.org/10.1177/1120672119857501

11. Mokhtarzadeh A, McClelland C, Lee MS, Smith S, Harrison AR. The bleph and the brain: the effect of upper eyelid surgery on chronic headaches. Ophthalmic Plast Reconstr Surg 2017;33(3):178-81.

https://doi.org/10.1097/IOP.0000000000000686

12. Papadopulos NA, Hodbod M, Henrich G, Kovacs L, Papadopoulos $\mathrm{O}$, Herschbach $\mathrm{P}$, et al. The effect of blepharoplasty on our patient's quality of life, emotional stability, and self-esteem. J Craniofac Surg 2019;30(2):377-83. https://doi.org/10.1097/SCS.0000000000005057

13. Bater KL, Ishii M, Nellis JC, Joseph A, Papel ID, Kontis $\mathrm{TC}$, et al. A dual approach to understanding facial perception before and after blepharoplasty. JAMA Facial Plast Surg 2018;20(1):43-9.

https://doi.org/10.1001/jamafacial.2017.1099

14. Przylipiak M, Przylipiak J, Terlikowski R, Lubowicka E, Chrostek L, Przylipiak A. Improvements in the perception of facial attractiveness following surgical aesthetic treatment; study based on online before and after photos. J Cosmet Dermatol 2019;18(1):296-300.

https://doi.org/10.1111/jocd.12818

15. Hahn S, Holds JB, Couch SM. Upper lid blepharoplasty. Facial Plast Surg Clin North Am 2016;24(2):119-27.

https://doi.org/10.1016/j.fsc.2016.01.002
16. Alghoul M. Blepharoplasty: anatomy, planning, techniques, and safety. Aesthetic Surg J 2019;39(1):10-28.

https://doi.org/10.1093/asj/sjy034

17. Neves JC, Medel Jiménez R, Arancibia Tagle D, Vásquez LM. Postoperative care of the facial plastic surgery patient - forehead and blepharoplasty. Facial Plast Surg 2018;34(6):570-8. https://doi.org/10.1055/s-0038-1676354

\section{EFFECTS OF UPPER LID BLEPHAROPLASTY ON VISUAL FUNCTION AND QUALITY OF LIFE IN PATIENTS WITH DERMATOCHALASIS: A CLINICAL CASE}

I. Kaukènaitė, J. Čemerkaitė, R. Liutkevičienė

Keywords: dermatochalasis, blepharoplasty, visual function, patient satisfaction.

Summary

Dermatochalasis is characterized by lax skin in the bilateral upper eyelids. Age is recognized as the major risk factor for sagging eyelids. Other risk factors include male sex, lighter skin color, high body mass index, and possibly current smoking. Blepharoplasty is a surgical procedure in which the eyelid skin, orbicularis oculi muscle, and orbital fat are excised, redraped, or sculpted to rejuvenate the esthetic look of the patient along with correction of any functional abnormality. Complications from upper lid blepharoplasty are usually minor, and careful surgical planning and meticulous technique can prevent most complications. The aim of this study is to present a clinical case and review newest literature on changes in objective and subjective visual function, patient's quality of life and patient satisfaction with upper lid blepharoplasty. In this case report we present a 57-year-old woman who complained of upper visual field defects, heavy upper eyelid feeling, eyelid skin irritation and uncomfortable viewing position and underwent an upper lid blepharoplasty. Clinical examination revealed excess skin in both upper eyelids covering the outer edges of the eyelid slit and lashes. Removal of the surplus skin with upper eyelid blepharoplasty increases visual function by reducing upper visual field defects, improving contrast sensitivity, astigmatism, and higher order aberrations. Subjective patient-reported symptoms such as visual field restriction, backward head tilt, heavy upper eyelid feeling, headache, and upper eyelid skin irritation improve after upper blepharoplasty. Upper blepharoplasty positively influences the patient's quality of life postoperatively. Patients are generally very satisfied with the result of the operation.

Correspondence to: ievakau@gmail.com

Gauta 2021-05-06 